M. ĆULIĆ, ${ }^{1}$ G. STOJADINOVIĆ, ${ }^{1}$ L. MARTAĆ, ${ }^{1}$ and M. SOKOVIĆ ${ }^{1}$

\title{
USE OF THE HURST EXPONENT FOR ANALYSIS OF ELECTROCORTICAL EPILEPTIFORM ACTIVITY INDUCED IN RATS BY ADMINISTRATION OF CAMPHOR ESSENTIAL OIL OR 1,8-CINEOLE
}

Received December 1, 2009.

In this study, we investigated the presence of long-range correlation effects in the electrocortical activity of rats using the Hurst exponent $(H)$ calculated by dispersion analysis (DA) and an aggregated variance method (AGV). A slow decline of the autocorrelation function during time expansion and the existence of a correlation between distant time points of electrocorticograms (ECoGs) were shown to be typical of various pathophysiological states. In these cases, the $H$ values were within a $0.5<H<1$ range. A particularly slow decay of the autocorrelation function is typical of a long-range dependence (LRD). We found that ECoGs after i.p. administrations of camphor essential oil or its main constituent, 1,8-cineole, included attacks of uncontrolled electrical discharges and showed the presence of longrange correlation effects. Such findings are in agreement with recent data obtained by other authors and suggest that initiation of seizures can be predicted by certain ECoG indices. We estimated the critical period where the $H$ values for ECoGs containing uncontrolled electrical discharges continuously increased within a few minutes before the attack. We believe that the AGV demonstrates certain advantages over DA in calculations of the $H$.

KEYWORDS: electrocorticogram, Hurst exponent, long-range correlations, epileptiform attacks.

\section{INTRODUCTION}

Application of nonlinear methods in the analysis of cerebral electrical activity demonstrates that the respective models are useful for interpreting complex pathophysiological phenomena, such as episodes of abrupt transitions and chaotic behavior [1]. Endogenous brain oscillations reflected in the electroencephalograms (EEGs) or electrocorticograms (ECoGs) have fractal properties, which are relevant to certain neurocognitive functions in health and disease. The fractal processes defined by self-similarity are in simple relations with the fractal dimension (FD) or the Hurst exponent $(H)$ of various processes $[2,3]$. The complexity of epileptiform EEG signals is evaluated by estimation of their FD, $H$, and other nonlinear measures [4-6]. It was found that the $H$ values of EEG seizure activity significantly increased before initiation of ictal activity, and the $H$ value decreased after ictal attacks [7]. Hence, we believe

\footnotetext{
'Institute for Biological Research "Siniša Stanković," University of Belgrade, Belgrade, Serbia.

Correspondence should be addressed to M. Culić

(e-mail: milkacul@ibiss.bg.ac.rs).
}

that these properties can be used for prediction of epileptiform electrographic seizures. There are different approaches to the investigation of the neurophysiological mechanisms crucial for understanding of the processes of interictal-to-ictal transition in human epilepsy; these are, in particular, computational models of EEG activity [8] and experimental animal models $[9,10]$. We described some characteristic changes in the spectral, wavelet, and Higuchi's FD parameters of electrocortical activity in a rat model of acute seizures [9-13]. The aim of this study was to find characteristic changes in the $H$ of parietal electrocortical activity by the comparative use of various methods in the rat acute model of epilepsy provoked by parenteral administrations of camphor essential oil or 1,8-cineole (the main constituent of this oil). Preliminary results of this study have already appeared [14].

\section{METHODS}

Operative procedures and the acute experimental model. In this study, we investigated data obtained from experimental animals used in previous studies 
for other purposes. Briefly, the experiments were performed on adult Wistar male rats in accordance with the rules of the European Council Directive (86/609/EEC) for the care and use of laboratory animals and approved by the Ethical Committee of the Institute for Biological Research (University of Belgrade, Serbia). The surgery was done under Nembutal (Serva, Germany) anesthesia. An initial dose of $35 \mathrm{mg} / \mathrm{kg}$ and subsequent injections of $\sim 8 \mathrm{mg} / \mathrm{kg}$ every $50-60$ min when necessary were used to obtain relatively light stable barbiturate anesthesia throughout the experiment. Each animal was mounted in a stereotaxic apparatus. Partial round-shaped craniotomies were made over the parietal cerebral cortex (P 2.0 to $2.5 \mathrm{~mm}$ and L/R 2.0 to 2.5 with respect to the bregma). Acute seizures were induced experimentally by i.p. administrations of 1,8-cineole (Sigma, USA) at a dose of $300 \mu 1 / \mathrm{kg}$ or camphor essential oil (Institute for Medicinal Plant Research "Josif Pancic," Serbia) at a dose of $600 \mu \mathrm{l} / \mathrm{kg}$ (dissolved in $1 \mathrm{ml}$ of saline), as was described in our earlier study [12]. Each experiment lasted about $180 \mathrm{~min}$; within this period, a 30-minlong control interval (before camphor oil/cineole administration) and a 120-min-long interval after the above administration were differentiated.

Acquisition of ECoGs. Local field potentials of the cerebral cortex (ECoGs) were recorded using epidurally positioned silver ball electrodes or superficially positioned intracortical tungsten microelectrodes, with a ground electrode laid over the frontal bone and temporal muscles. The ECoGs were amplified and filtered by a multichannel processor with pass filters from $\mathrm{DC}$ to $1 \mathrm{kHz}$ and a $50-\mathrm{Hz}$ notch. The signals were digitized at the sampling rate of $256 \mathrm{sec}^{-1}$ and filtered off-line to avoid artifacts that occasionally appeared at 61 and $106 \mathrm{sec}^{-1}$. Electrophysiological recordings were sequential, and each recorded sample lasted usually $121 \mathrm{sec}$. Recordings were repeated every 5$10 \mathrm{~min}$; sometimes the recorded sequence lasted 1,800 sec in continuum after oil/cineole administration.

Calculation of the Hurst exponent. The scaling properties of a given discrete time series $X=\left\{X_{1}, X_{2}, \ldots\right.$ $\left.\ldots \mathrm{X}_{\mathrm{N}}\right\}$ can be expressed through the dependence of the autocorrelation function $C(k)$ vs the Hurst exponent $(H)$ in terms of a large-time lag, $k$ :

$C(k)=\frac{1}{N-k} \sum_{i=1}^{N-k} X_{i} \cdot X_{i+k} \sim k^{2 H-2}$

In this case, if $N \rightarrow \infty, \sum_{k=1}^{N} C(k) \rightarrow \infty$, and $H>0.5$, then the process is called a long-range-correlated one, or a long-memory process [15]. In the literature, this behavior of time series has been described as a "persistent" behavior, which means that an increasing or a decreasing trend of the time series in the past is followed with the same trend in the future. When $H<$ $<0.5$, the time series has long-range anticorrelations, or an "antipersistent" behavior. This means that if the value of the time series is "up," then at the next moment it is "down," and vice versa. In the case where $H=$ $=0.5$, the process has short-range correlations typical of ordinary uncorrelated Brownian motion.

Among various methods for determining the $H$, like rescaled range statistics [3], wavelet methods [16], etc., we have chosen in this study dispersion analysis (DA) [17] and an aggregation variance method (AGV) [18] taking into account their simplicity and fast computability.

Dispersion analysis is based on the variability of local averages over windows of length $\tau$. These local averages are determined by averaging of neighboring pairs of points, and calcalation of the standard deviation $\sigma(\tau)$. The entire procedure is repeated for different values of $\tau$ having in mind the expression $\sigma^{2} \sim \tau^{2 \mathrm{H}-2}$ for self-similar processes; the quantity $H$ is estimated as the slope of the regression function of $\log (\sigma(\tau) /$ $\sigma\left(\tau_{0}\right) v s \log \left(\tau / \tau_{0}\right)$, where $\left.\tau_{0}\right)$ is the size of the reference window.

In the $\mathrm{AGV}$, a new aggregated series is obtained by dividing a given time series $\mathrm{X}=\left\{\mathrm{X}_{1}, \mathrm{X}_{2}, \ldots\right.$ $\left.\ldots \mathrm{X}_{\mathrm{N}}\right\}$ into blocks of length $m$ and averaging the series of each block according to the formula

$$
X^{(m)}(k)=\frac{1}{m} \cdot \sum_{i=(k-1) m+1}^{k m} X_{i} ; \quad k=1,2, \ldots \operatorname{int}(N / m) .
$$

In the next step, the variance of the aggregated series is calculated:

$\operatorname{Var}\left(X^{(m)}\right)=\frac{1}{N / m} \cdot \sum_{k=1}^{N / m}\left(X^{(m)}(k)-\bar{X}\right)^{2}$,

where $\bar{X}$ is the mean value of a given time series $X$. For successive values of $m$, the variance of the aggregated series $v s m$ is plotted on a $\log -\log$ plot. The result is a straight line with slope $2 \mathrm{H}-2$. Large values of $\mathrm{N} / \mathrm{m}$ and $m$ ensure that the length and number of blocks are sufficiently large, and if $H>0.5$, the time series shows long-range correlation. 


\section{RESULTS}

We calculated the $H$ values by two methods (AGV and DA) in the groups of ECoG signals with the presence of epileptiform discharges, which appeared after camphor oil or cineole administrations (Fig. 1). We determined the asymptotic value of $H$ for a 121-sec-long period of observation (at the sampling rate of $f_{\mathrm{s}}=256 \mathrm{sec}^{-1}$, the total number of signal points was $\left.N=f_{s} \cdot \tau=30976\right)$.

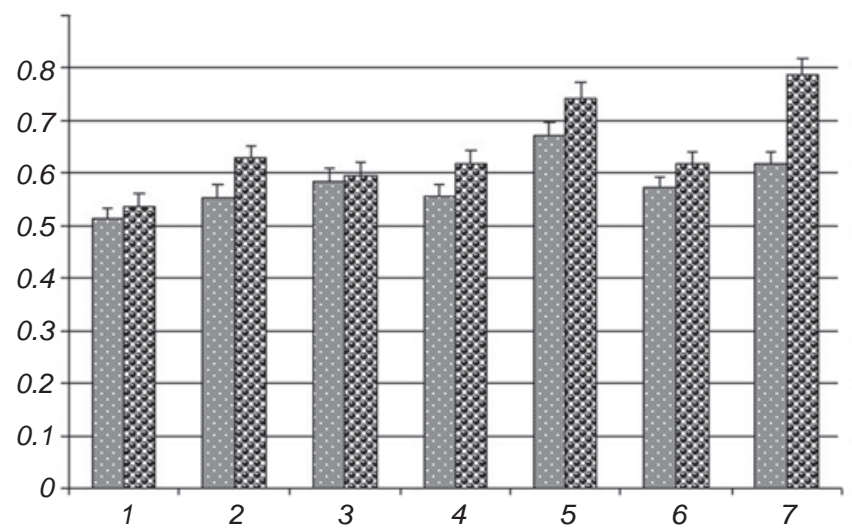

F i g. 1. Values of the Hurst exponent ( $H$, vertical scale) for ECoG signals containing epileptiform discharges induced by i.p. administrations of camphor essential oil or its main constituent, 1,8cineole. The $\mathrm{H}$ values were calculated using dispersion analysis, DA, and an aggregated variance method, AGV (left and right columns, respectively); 1-7 are consecutive time series.

Р и с. 1. Величини експоненти Харста ( $H$; вертикальна шкала) для сигналів ЕКоГ, що вміщувала епілептиформні розряди, індуковані введенням камфорної олії або іiї основної складової (1,8-цинеолу).

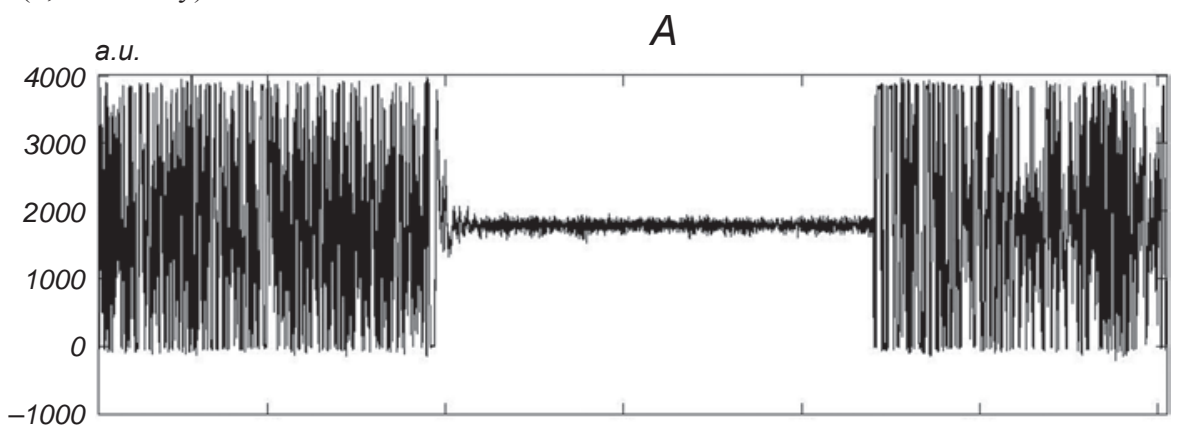

$B$

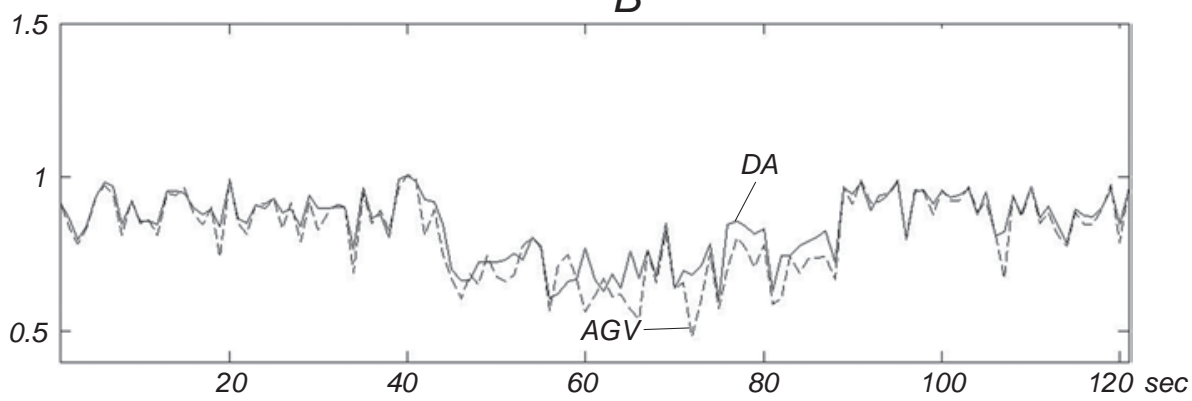

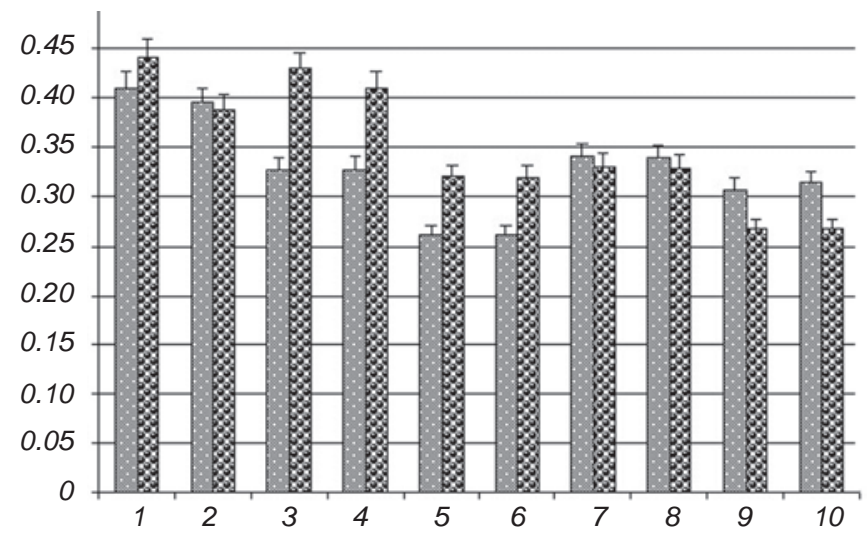

F i g. 2. Values of the Hurst exponent ( $H$, vertical scale) of 10 time series of ECoG signals recorded in rats before camphor/cineole administration (series 1, 3, 7, 8, 9, and 10) and 20 min after camphor administration (time series 2) and also $5 \mathrm{~min}, 15 \mathrm{~min}$, and $45 \mathrm{~min}$ after cineole administration (time series 4, 5, and 6). In these cases, there were no epileptiform attacks in the ECoG samples. Other designations are the same as in Fig. 1.

Р и с. 2. Величини експоненти Харста ( $H$; вертикальна шкала) для 10 сегментів ЕКоГ, зареєстрованих перед уведенням камфори/цинеолу $(1,3,7,8,9,10)$, через 20 хв після введення камфори, а також через 5, 15, та 45 хв після введення цинеолу (4, 5 та 6 відповідно).

The $H$ values were below 0.5 (Fig. 2) for the investigated ECoG signals recorded before camphor oil and cineole administrations, as well as in cases after camphor/cineole administrations where epileptiform attacks did not appear. This fact was an indication of the absence of the long-correlation effects, which points to unpredictability, in the sense that a continuous trend
F i g. 3. Time dynamics of the Hurst exponent $(H$, panel $\mathrm{B})$ in ictal and interictal phases of a time series with epileptiform seizures in ECoG (panel A). Abscissa) Time, sec; ordinate in A) arbitrary units. In B) Solid and dashed lines are the $H$ values calculated using dispersion analysis (DA) and an aggregated variance method (AGV).

Р и с. 3. Часова динаміка експоненти Харста $(H ; B)$ у межах іктальної та інтеріктальної фаз записів ЕКоГ 3 присутністю епілептиформної судомної активності $(A)$. 


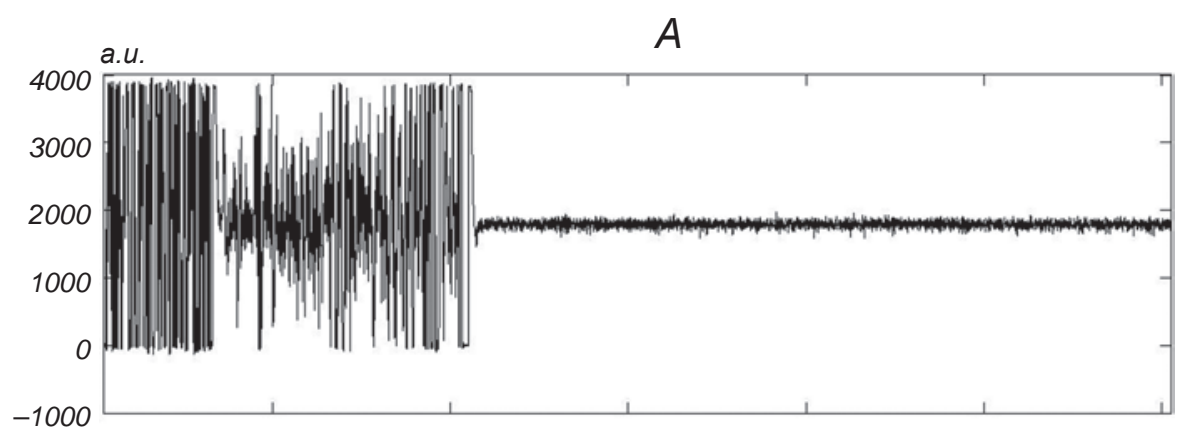

$B$

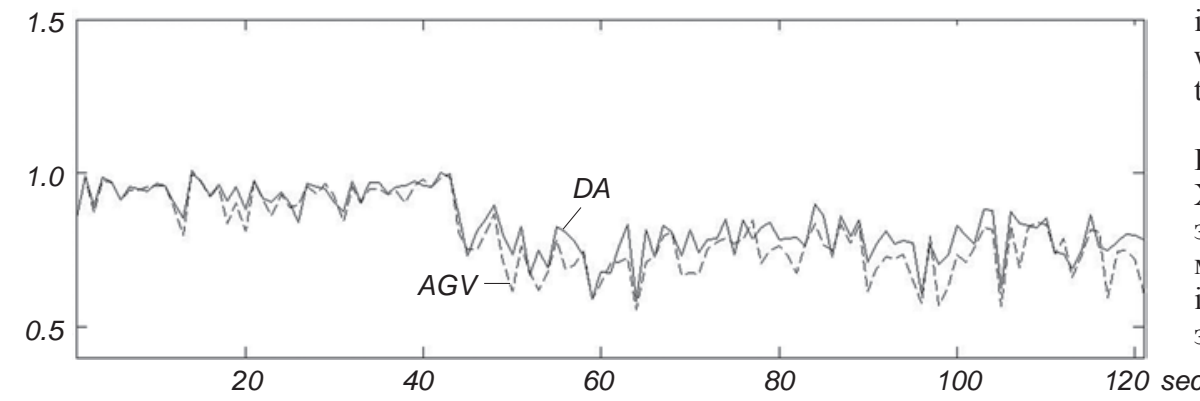

A

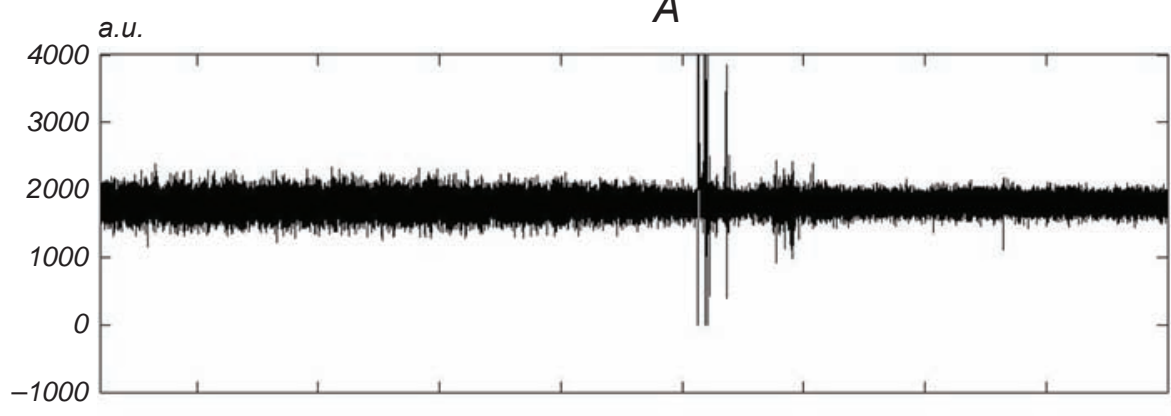

$B$

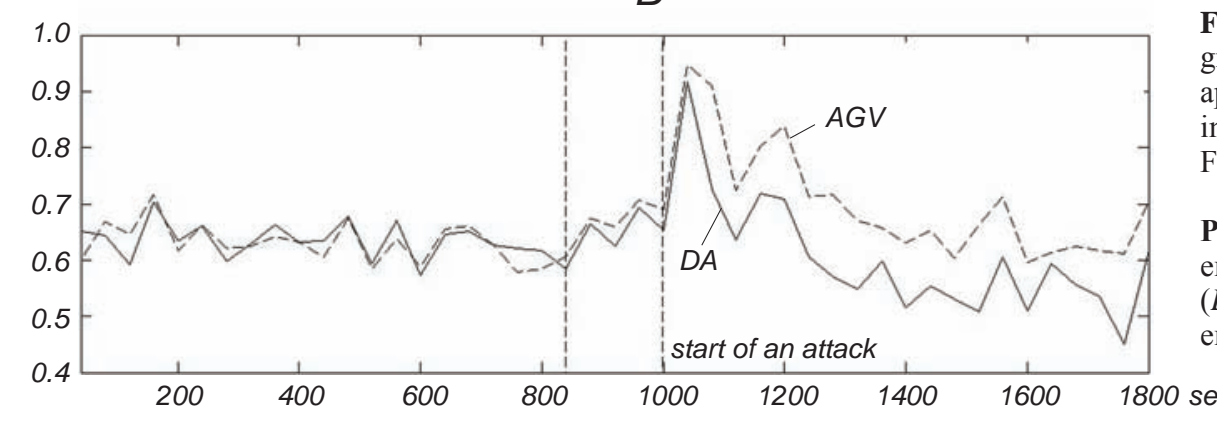

of growth or decline in the amplitude/frequency of the signal does not exist. In order to examine the nonlinear properties of ECoG further, we also determined the time evolution of the $H$. We examined 121-sec-long time series after camphor oil administration with ictal and interictal activity divided into shifted nonoverlapping windows with a width of 256 points $(1 \mathrm{sec})$, within
F i g. 4. Time dynamics of the Hurst exponent in ictal and postictal phases of a time series with epileptiform seizures. Designations are the same as in Fig. 3.

Р и с. 4. Часова динаміка експоненти Харста (величини $H$ були розраховані за допомогою дисперсійного аналізу та методу згрупованих варіанс; (B) у межах іктальної та постіктальної фаз зразка ЕКоГ 3 епілептиформними розрядами $(A)$.
F i g. 5. Critical period for a continuously growing Hurst exponent $(H)$ as a sign of appearing of epileptiform seizure discharges in ECoG. Designations are the same as in Figs. 3 and 4.

Р и с. 5. Критичний період, у межах якого експонента Харста $(H)$ постійно зростала $(B)$, що $\epsilon$ ознакою можливості появи епілептиформних розрядів у ЕКоГ $(A)$. 
uncontrolled electrical discharges (ictal activity) shows a correlation between the distant time points of the signal and suggests the possibility of prediction of an epileptic attack. For this purpose, we analyzed 1,800-seclong time series containing manifestations of epileptic attacks and determined the time development of $H$. In this case, the choice of an optimal number of points in a moving time window is essential. Although free to choose a greater width of the window, we chose values closer to an asymptotic value of the $H$, since the number of points cannot be too large because of possible technical implementations. We have chosen a window width containing 10,240 points $(80 \mathrm{sec})$ and applied DA and AGV methods for calculating the $H$ values. We found that, starting from the moment of about 800 sec after cineole administration and thereafter, the $H$ value started to grow continuously, with no global variation until the beginning of an epileptiform attack, when it reached a top value (Fig. 5). We call this period before the beginning of the epileptiform attack the critical period. In our case, the duration of this period was $3.2 \mathrm{~min}$ (about $190 \mathrm{sec}$ ). By analysis of Fig. 5, it can be concluded that changes in the critical period were more clearly expressed when we used the AGV method. Of course, this finding must be verified on a larger number of cases in future research.

\section{DISCUSSION}

We investigated the nonlinear properties of the time series in the animal model of epileptic seizures by calculation of the $H$ values for the electrocortical activity before and after epileptogenic drug administration. In all cases, the $H$ values were above 0.5 , which points to the fact that long-range correlation effects do appear in ECoGs during uncontrolled electrical discharges. Our results of calculation of the $H$ values are in accordance with the findings obtained by other authors with respect to nonlinear properties of brainproduced signals [7, 18]. Computer simulations of such brain signals with model neural networks showed that the signal possesses much greater predictability when long-range correlation effects predominate. Thus, a trend toward increasing or decreasing the amplitude of the signal in the past will be followed by the same trend in the future, as is in the case where the epileptic attack develops. In particular, when $H \rightarrow 1$, these effects bear the name long-memory effects, because, roughly speaking, the signal "remembers" its previous state.
We used two methods for the determination of the $H$ (DA and AGV) in order to obtain more accurate results, which could confirm our assumptions. It is clear that there is an increase in the $H$ values during seizures, which points to an increase in the degree of self-similarity and the appearance of longrange correlation. On the other hand, the connection between the FD and $H$ described by the formula $F D=2-H[15]$ means that, during epileptic attacks, there is a decrease in the FD values. This was noticed in our recent study [13] where we mainly calculated the mean FD values of electrocortical activity without separation of the ictal vs interictal activity during 121sec-long sequences. This circumstance could mask the FD value during particularly short-lasting epileptiform discharges. The $H$ values in the acute seizures induced by camphor oil/cineole parenteral administration are in agreement with the results of other researchers, who found significant decreases in the FD and an increase in the slow-frequency range power spectra of the cortical activity at the beginning of a grand mal attack [19]. Analysis of ECoGs in rats just before the first uncontrolled discharges (an epileptiform attack) and thereafter showed the appearance of long-range correlation and demonstrated the possibility to predict the development of an epileptic attack. This fact can serve as a starting point for further research. We should keep in mind the interesting experimental results obtained by Barbaro et al. [20] who hypothesized that the slowfrequency ECoG ranges play a key role in functioning of the brain. An interesting quantitative approach using fractal analysis [21] for identifying the onset of epileptic seizures in the intracranial ECoG in patients with refractory mesial temporal lobe epilepsy during the evaluation of the neurosurgery effects provides a promising computational tool for determination of the electrographic seizure onset in clinical applications. It should also be mentioned that, in the acute animal model of seizures, we showed the eventual cerebellar involvement in the genesis of epilepsy using linear and nonlinear analytic approaches [22]. The application of a wavelet-based functional mixed-effect model [23] for analysis of the cerebral and cerebellar activity in acute seizures can provide researchers with more details from the aspect of not only prediction but also termination of epileptic attacks.

Acknowledgments. This study was supported by the Serbian Ministry of Science and Technological Development (Project No.14021). The kindness of Dr. G. Keković in providing us with the software for calculation of the Hurst exponent is highly appreciated. 
М. Чуліч ${ }^{1}$, Г. Стоядіновіч${ }^{1}$, Л. Мартач ${ }^{1}$, М. Соковіч ${ }^{1}$

\section{АНАЛІЗ ЭЛЕКТРОКОРТИКАЛЬНОЇ АКТИВНОСТІ, ЯКА МІСТИЛА В СОБІ ІНДУКОВАНІ ВВЕДЕННЯМИ КАМФОРНОЇ ОЛІЇ АБО 1,8-ЦИНЕОЛА ЕПІЛЕПТИФОРМНІ ЕПІЗОДИ, 3 ВИКОРИСТАННЯМ ЕКСПОНЕНТИ ХАРСТА}

\author{
${ }^{1}$ Інститут біологічних досліджень “Сініша Станковіч”, \\ Бєлград (Сербія). \\ P е 3 ю м е
}

Ми виявляли присутність ділянок тривалої кореляції в електрокортикограмах (ЕКоГ) щурів, використовуючи побудову експоненти Харста $(H)$. Останню розраховували на основі дисперсійного аналізу (DA) або методу згрупованих варіанс (AGV). В ЕКоГ, зареєстрованих у різних фізіологічних станах, спостерігалися повільне затухання аутокореляційної функції при розтягненні часової шкали та кореляція між віддаленими часовими точками. У цих випадках значення $H$ знаходилося в діапазоні $0.5<H<1.0$. Особливо повільне затухання аутокореляційної функції свідчить про наявність довгодіапазонної залежності (LRD). Ми встановили, що в ЕКоГ, зареєстрованих після внутрішньоочеревинних ін'єкцій камфорної олії або її основного активного компонента 1,8-цинеолу, були наявні спалахи неконтрольованих розрядів (епілептиформні епізоди) та прояви тривалої кореляції. Ці спостереження узгоджуються 3 результатами, про котрі повідомляли інші автори, та вказують на можливість передбачати можливий розвиток судомної активності. Як виявилося, критичний період, у межах котрого величина $H$ для ЕКоГ з наявністю епілептиформних епізодів і котрий передує розвитку судомної активності, складає декілька хвилин. Ми вважаємо, що метод AGV при розрахунку $H$ має преференції порівняно з DA.

\section{REFERENCES}

1. R. U. Acharya, O. Faust, N. Kannathal, et al., "Nonlinear analysis of EEG signals at various sleep stages," Comp. Meth. Prog. Biomed., 80, 37-45 (2005).

2. T. Higuchi, "Approach to an irregular time series on the basis of the fractal theory," Physica D, 31, 277-283 (1988).

3. H. E. Hurst, R. P. Black, and Y. M. Simaiki, Long-Term Storage: An Experimental Study, Constable, London (1965).

4. M. Kannathai, S. K. Puthusserypady, and L. C. Min, "Complex dynamics of epileptic EEG," in: Conf. Proc. IEEE Eng. Med. Biol. Soc., 26, 604-607 (2004).

5. N. Kannathai, U. R. Acharya, C. M. Lim, et al., "Characterization of EEG - A comparative study," Comput. Methods Programs Biomed., 80, 17-23 (2005).

6. W. Klonowski, E. Olejarczyk, and R. Stepien, "Nonlinear dynamics of EEG-signal reveals influence of magnetic field on the brain," in: Proceedings of the 22nd Annual International Conference of the IEEE, 4, 2955-2958 (2000).

7. K. P. Indiradevi, E. Elias, and P. S. Sathidevi, "Complexity analysis of electroencephalogram records of epileptic patients using Hurst exponent," Int. J. Med. Eng. Inform., 1, 368-380 (2009).

8. F. Wendling, A. Hernandez, J. J. Bellanger, et al., "Interictal to ictal transition in human temporal lobe epilepsy: Insights from a computational model of intracerebral EEG," J. Clin. Neurophysiol., 22, 343-356 (2005).

9. G. Grbić, M. Ćulić, Lj. Martać, et al., "Camphor oil poisoningspectral analysis of rat brain activity," Acta Physiol. Pharmacol. Serbica, 42, 233-238 (2006).

10. J. A. Gorter, E. A. Van Vliet, E. Aronica, et al., "Long-lasting increased excitability differs in dentate gyrus vs. CA1 in freely moving chronic epileptic rats after electrically induced status epilepticus," Hippocampus, 12, 311-324 (2002).

11. M. Ćulić and G. Keković, " Electrocortical activity of rat brain and cineole effect - spectral and continual wavelet analysis," in: Abstracts of the IV Congress of Serbian Society for Neuroscience, September 11-14, 2008 [in Serbian], Kragujevac (2008), p. 330.

12. M. Ćulić, G. Keković, G. Grbic, et al., "Wavelet and fractal analysis of rat brain activity in seizures evoked by camphor essential oil and 1,8-cineole," Gen. Physiol. Biophys., Special Issue, 28, 33-40 (2009).

13. G. Grbic, M. Ćulić, M. L. Martac, et al., "Effect of camphor essential oil on rat cerebrocortical activity detected by changes in fractal dimension," Arch. Biol. Sci., 60, 547-553 (2008).

14. G. Keković, G. Grbic, L. Martac, et al., "The nonlinear properties of EEG signals in acute model of epilepsy," in: Proceedings of the NEUROMATH Workshop, Leuven, March 12-13 (2009), p. 52.

15. A. Carbone, "Algorithm to estimate the Hurst exponent of high-dimensional fractals," Phys. Rev. E, 76, 056703 (2007).

16. I. Simonsen, A. Hansen, and O. M. Nes, "Determination of the Hurst exponent by use of wavelet transforms," Phys. Rev. E, 58, 278-2787 (1998).

17. J. E. Bassignthwaighte and G. M. Raymond, "Evaluation of the dispersion analysis method for fractal time series," Ann. Biomed. Eng., 23, 491-505 (1995).

18. P. Zhou, F. Li, W. Y. Liu, et al., "Fractal analysis in normal EEG and epileptic EEG of rats," in: Proceedings of the World Congress on Medical Physics and Biomedical Engineering, Springer, Berlin, Heidelberg (2007), pp. 1266-1269.

19. O. A. Rosso, S. Blanco, and A. Rabinowicz, "Wavelet analysis of generalized tonic-clonic epileptic seizures," Signal Processing, 83, 1275-1289 (2003).

20. N. M. Barbaro, M. S. Berger, R. T. Canolty, et al., "High gamma power is phase-locked to theta oscillations in human neocortex," Science, 313, 1626-1628 (2006).

21. R. Esteller, G. Vachtsevanos, J. Echauz, et al., "Fractal dimension characterizes seizure onset in epileptic patients," in: Proceedings of the IEEE International Conference on Acoustics, Speech and Signal Processing, 4, 2343-2346 (1999).

22. M. Ćulić, G. Keković, L. Martac, et al., "Cerebellar role in brain injury and epilepsy: Linear and nonlinear analysis of electrocortical activity," in: Proceedings of the VI Motor Control Conference, September 5-8, 2009, Varna (2009), pp. $39-40$.

23. D. J. Davidson, "Functional mixed-effect models for electrophysiology responses," Neurophysiology, 41, 79-87 (2009). 